\title{
The [Sensitivity of Suppressed and Unsuppressed [lon Strains of Escherichia coli to Chemical Agents which Induce Filamentation
}

\author{
By R. JAMES AND N. E. GILLIES \\ Department of Biology as Applied to Medicine, \\ The Middlesex Hospital Medical School, London, WI $P$ 6DB
}

(Received I 2 January 1973)

\begin{abstract}
SUMMARY
The sensitivities of lon strains of Escherichia coli to the filament inducing agents nalidixic acid, gentian violet, crystal violet and penicillin were examined. The strains used included those in which the lon gene is suppressed by sul, exr and rec as well as strains in which the Lon phenotype is expressed. The sensitivity of the bacteria to agents which act on DNA was reduced when lon was suppressed, but the extent of the decrease in sensitivity was dependent on the mechanism by which suppression was effected. Sensitivity to penicillin, on the other hand, was reduced only in the sul strain and by a mechanism which appears to be independent of the direct suppression of lon. A model to account for these results indicates possible sites at which the lon, $\operatorname{sul}, \operatorname{exr} A$ and $\operatorname{rec} A$ genes are expressed.
\end{abstract}

\section{INTRODUCTION}

Many factors control the radiation sensitivity of strains of Escherichia coli. Apart from the well-established enzymatically controlled repair processes which reduce the expression of radiation damage (Boyce \& Howard-Flanders, I964; Setlow \& Carrier, I964; Rupp \& Howard-Flanders, I968), a major factor in determining radiation response is the sensitivity of processes directly involved in mechanisms controlling division of the bacteria. In some strains, septum formation, and therefore complete division of irradiated bacteria, is inhibited without significant concomitant effects on increase in mass, so that they grow into nonseptate multinucleated filaments which eventually lyse (Witkin, 1947; Alper, I957; Van de Putte, Westenbroek, \& Rörsch, I963; Adler \& Hardigree, 1965; Brown \& Gillies, 1972). This defect, the expression of a gene originally called $\mathrm{fl}^{+}$in $E$. coli B and lon in strains of $E$. coli $\mathrm{KI} 2$ but now generally referred to as lon, is mainly responsible for the high radiosensitivity of such strains. In several strains of $E$. coli the Lon phenotype is suppressed by other genes such as sul, exr $A$ and recA (Donch, Green \& Greenberg, I968; Donch, Chung \& Greenberg, 1969; Green, Greenberg \& Donch, 1969), so that after irradiation little or no filamentation is observed. In the $s u l$ strain $E$. coli $\mathrm{B} / \mathrm{r}$ the suppression of lon confers radiation resistance (Donch et al. 1969), but the same effect is not observed in exrA and recA strains and this is presumably because of the marked radiation sensitivity arising directly from these mutations (Howard-Flanders \& Boyce, 1966; Mattern, Zwenk \& Rörsch, 1966). The mechanisms by which expression of the Lon phenotype is suppressed are unknown at present.

Several chemical agents also cause filamentation in unsuppressed lon strains, e.g. nalidixic acid (Kantor \& Deering, I968; Walker \& Pardee, I968), gentian violet (Normark \& Westling, I97I), crystal violet (Walker, Shafiq \& Allen, I97I), and penicillin (Leighton \& 
Table I. Relevant markers and source of Escherichia coli strains used

\begin{tabular}{|c|c|c|}
\hline Strain & Genotype & Source \\
\hline $\mathbf{B}$ & lon sul+ ${ }^{+}$ & Laboratory stock \\
\hline $\mathbf{B}_{\mathrm{s}-2}$ & lon sul ${ }^{+}$exr $A$ & M.H.L. Green \\
\hline$B_{s-11}$ & lon $s u l^{+} \operatorname{rec} A$ & M.H.L. Green \\
\hline$B_{8-12}$ & lon sul+ $u v r$ & M.H.L. Green \\
\hline $\mathbf{B} / \mathbf{F}^{\prime}$ lon $^{+}$ & lon sul ${ }^{+} \mathbf{F}^{\prime}$ lon $^{+}$ & Laboratory stock (Farnsworth \& James, 1972) \\
\hline & lon sul & Laboratory stock \\
\hline SB3IOO & lon sul $/ \mathrm{F}^{\prime}$ ara ${ }^{+}$ & E. Englesberg \\
\hline
\end{tabular}

Donachie, 1970). The sites of action of some of these agents are known. Nalidixic acid and gentian violet cause filamentation by inhibiting DNA synthesis, whereas the activity of penicillin is restricted to the bacterial envelope. The mechanism of the action of crystal violet is less well understood.

This paper describes the effect of these agents on the colony-forming ability of several lon mutants of Escherichia coli and derivatives which carry mutations at sul, $\operatorname{rec} A, \operatorname{exr} A$ and $u v r$ loci. A model is put forward to account for the observations and to suggest sites in the bacterium at which these genes are expressed.

\section{METHODS}

Bacterial strains. The relevant genotypes and sources of the strains of Escherichia coli used are indicated in Table I. Stock cultures of these strains were maintained on slopes of Oxoid Blood Agar Base (BAB) at $4{ }^{\circ} \mathrm{C}$.

Growth conditions. Strains were grown overnight in Oxoid nutrient broth at $37^{\circ} \mathrm{C}$. They were then diluted $\mathrm{I}: \mathrm{IO}$ into fresh broth and incubation continued for a further $2 \mathrm{~h}$. For treatment with gentian violet, crystal violet and benzyl penicillin, it was convenient to incubate the bacteria, at suitable dilution, for $24 \mathrm{~h}$ on plates of BAB containing different concentrations of the agents. Colony counts were made at this time. For treatment with nalidixic acid, a few experiments only were made in this way because growth on BAB containing as little as $5 \mu \mathrm{g}$ of the $\mathrm{drug} / \mathrm{ml}$ was too slow to allow colony counts to be made after $24 \mathrm{~h}$ of incubation. Instead, the bacteria were diluted $\mathrm{I}: 5$ into Oxoid nutrient broth containing nalidixic acid (I00 $\mu \mathrm{g} / \mathrm{ml}$ ) and incubation continued at $37^{\circ} \mathrm{C}$. Samples of the suspension were removed at intervals, diluted in $0.067 \mathrm{M}$-phosphate buffer and plated on BAB. The conclusions drawn concerning the relative sensitivity of the bacteria to nalidixic acid were unaffected by the particular method used.

\section{RESULTS}

Sensitivity to nalidixic acid. The effect on survival of incubating different strains of Escherichia coli in nutrient broth containing nalidixic acid $(100 \mu \mathrm{g} / \mathrm{ml})$ is shown in Fig. I. The rate of killing of $E$. coli в was much more rapid than that of $E$. coli $\mathrm{B} / \mathrm{r}$ because of the marked filamentation induced in the unsuppressed lon strain by nalidixic acid (Green, Donch, Chung \& Greenberg, I969). That this is the main cause of the difference in sensitivity of these strains was supported by the finding that F-duction of lon into $E$. coli B by the method of Farnsworth \& James (1972) made this strain almost as resistant to nalidixic acid as $E$. coli $\mathrm{B} / \mathrm{r}$. Escherichia coli $\mathrm{B}_{8-12}$, which lacks the repair enzyme system controlled by one of the $u v r$ genes, was as sensitive to nalidixic acid as $E$. coli $\mathrm{B}$, but sensitivity to this agent was markedly reduced in the $\operatorname{rec} A$ strain $\left(E\right.$. coli $\left.\mathrm{B}_{\mathrm{s}-11}\right)$ and in the $\operatorname{exr} A$ strain $\left(E\right.$. coli $\left._{\mathrm{B}_{\mathrm{8}-2}}\right)$. Similar 


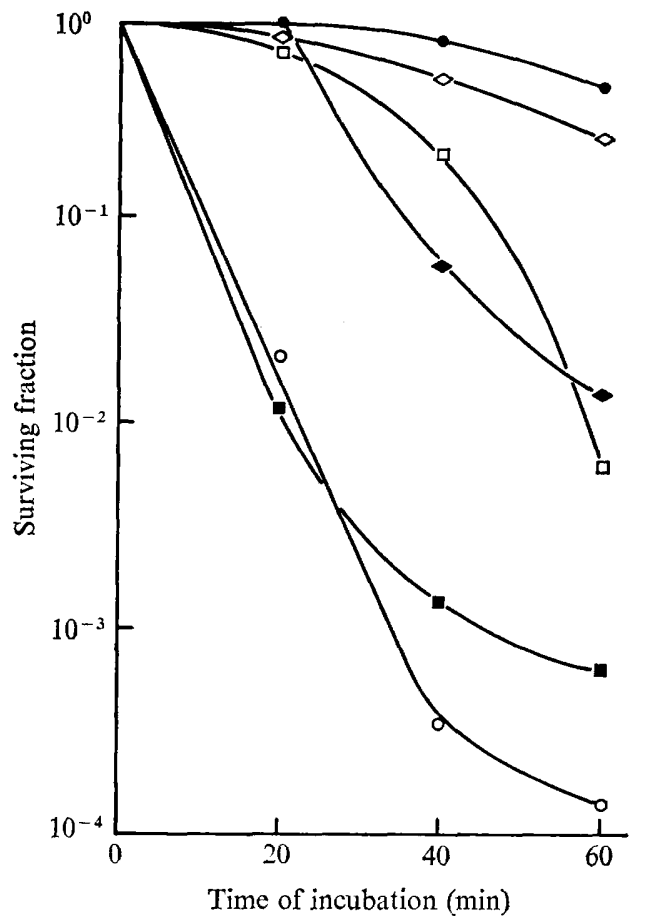

Fig. I

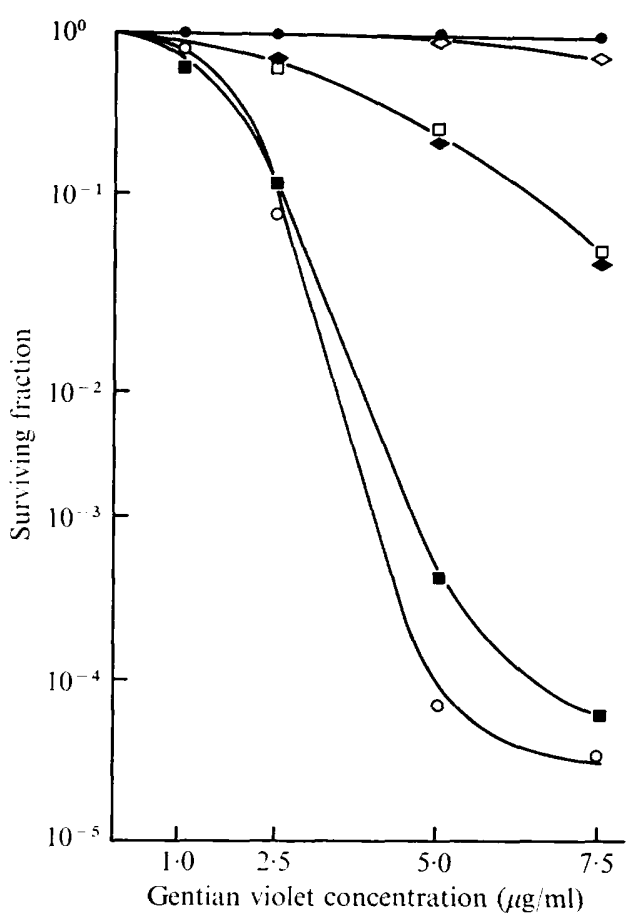

Fig. 2

Fig. I. Survival of Escherichia coli strains incubated with nalidixic acid. Bacteria were incubated at $37^{\circ} \mathrm{C}$ with shaking in nutrient broth containing $100 \mu \mathrm{g}$ nalidixic acid $/ \mathrm{ml}$ for the times indicated before plating on $\mathrm{BAB}$. $\mathrm{O}, E$. coli $\mathrm{B} ; \Theta, E$. coli $\mathrm{B} / \mathrm{r} ; \diamond, E$. coli $\mathrm{B} / \mathrm{F}^{\prime} \operatorname{lon}^{+} ; \diamond, E$. coli $\mathrm{B}_{8 \cdot 2}$; $\square$, E. coli $\mathrm{B}_{8-11} ; \square$, E. coli $\mathrm{B}_{8-12}$.

Fig. 2. Survival of Escherichia coli strains incubated with gential violet. Bacteria were plated at suitable dilutions on $\mathrm{BAB}$ plates containing various concentrations of gentian violet and incubated overnight at $37^{\circ} \mathrm{C}$. Symbols as for Fig. I.

observations on the rec and exr strains were made by Green, Donch, Chung \& Greenberg (I969).

Sensitivity to gentian violet. Gentian violet produced a response similar to that caused by nalidixic acid in the different strains tested (see Fig. 2).

Sensitivity to crystal violet. The effect of this compound on viability was examined in three strains only (Fig. 3). Again Escherichia coli $\mathrm{B} / \mathrm{r}$ was much more resistant to killing than was $E$. coli $\mathrm{B}$, confirming the observations of Rörsch, Edelman, Van Der Kamp \& Cohen (1962), but $E$. coli $\mathrm{B}_{\mathrm{8}-2}$ was almost as resistant as $E$. coli $\mathrm{B} / \mathrm{r}$ to this agent.

Sensitivity to benzylpenicillin. Escherichia coli $\mathrm{B} / \mathrm{r}$ was more resistant to inactivation by penicillin than was $E$. coli $\mathrm{B}$, as was observed previously by Rörsch et al. (1962). However, $E$. coli $\mathrm{B} / \mathrm{F}^{\prime}$ lon $^{+}$and the suppressed lon strains $E$. coli $\mathrm{B}_{8-2}$ and $E$. coli $\mathrm{B}_{8-11}$ as well as the $u v r$ strain $E$. coli $\mathrm{B}_{\mathrm{B}-12}$ were even more sensitive to the action of penicillin than was $E$. coli $\mathrm{B}$ (Fig. 4). Escherichia coli $\mathrm{SB} 3 \mathrm{I} \mathrm{OO}$, an $\mathrm{F}^{\prime}$ derivative of $E$. coli $\mathrm{B} / \mathrm{r}$ was almost as resistant as the parent strain, indicating that the $\mathrm{F}^{\prime}$ factor was not responsible for the high sensitivity of E. coli $\mathrm{B} / \mathrm{F}^{\prime}$ lon $^{+}$(Fig. 4). 


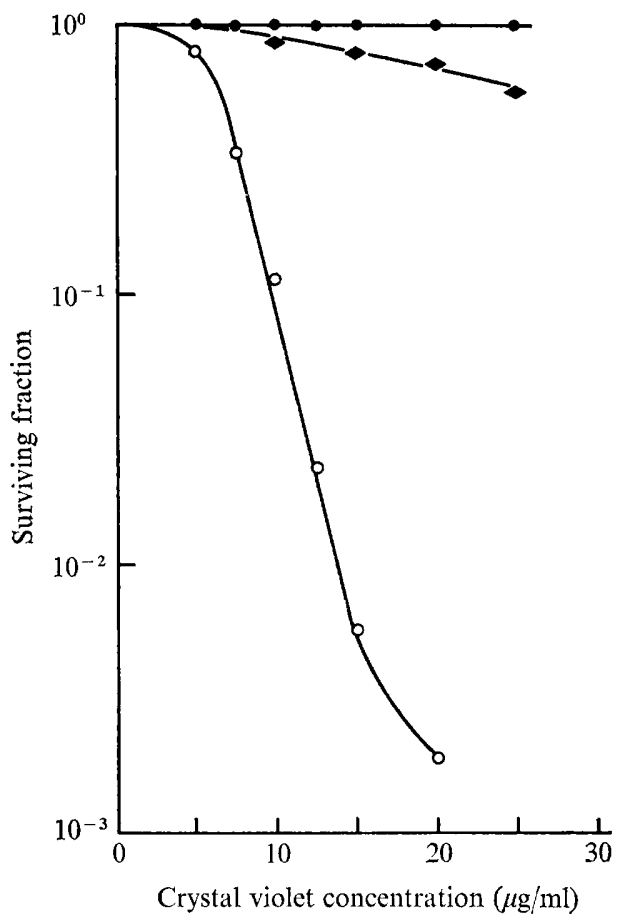

Fig. 3

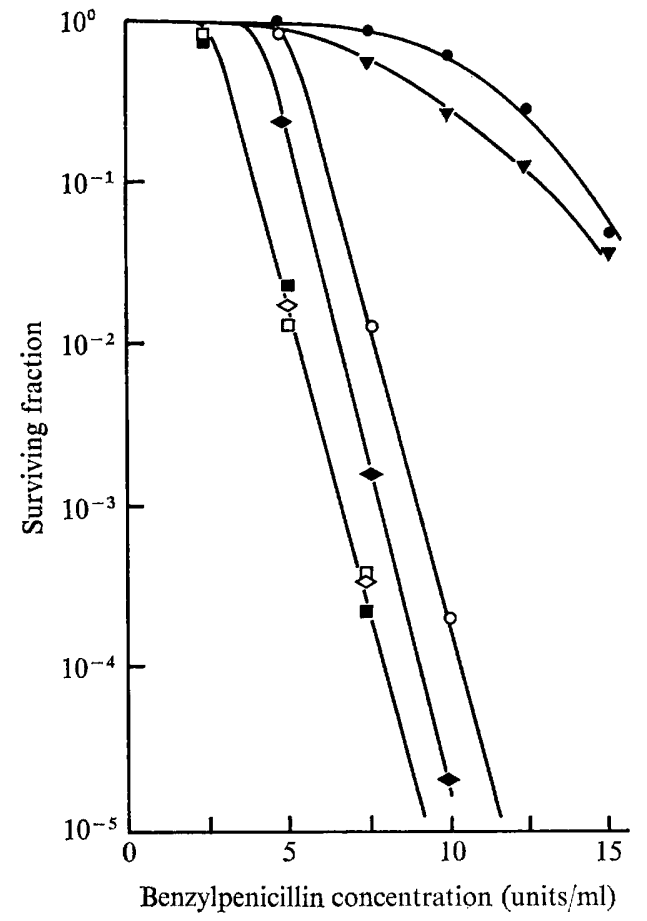

Fig. 4

Fig. 3. Survival of Escherichia coli strains incubated with crystal violet. Bacteria were plated at suitable dilution on $\mathrm{BAB}$ plates containing various concentrations of crystal violet and incubated overnight at $37^{\circ} \mathrm{C}$. O, E. coli $\mathrm{B} ; \bigcirc$, E. coli $\mathrm{B} / \mathrm{r} ; \diamond, E$. coli $\mathrm{B}_{\mathrm{8}-2}$.

Fig. 4. Survival of Escherichia coli strains incubated with benzylpenicillin. Bacteria were plated at suitable dilutions on BAB plates containing various concentrations of benzylpenicillin and incubated overnight at $37^{\circ} \mathrm{C}$. $\bigcirc, E$. coli $\mathrm{B} ; \ominus, E$. coli $\mathrm{B} / \mathrm{r} ; \diamond, E$. coli $\mathrm{B} / \mathrm{F}^{\prime} l o n^{+} . \diamond, E$. coli $\mathrm{B}_{\mathrm{8}-2} ; \square$, E. coli $\mathrm{B}_{\mathrm{s}-11} ; \mathbf{\square}$, E. coli $\mathrm{B}_{\mathrm{8}-12} ; \nabla$, E. coli $\mathrm{B} / \mathrm{r} / \mathrm{F}^{\prime}$ ara ${ }^{+}$.

\section{DISCUSSION}

The results show that there are marked differences in the relative sensitivities of lon strains of Escherichia coli to agents which induce filament formation.

Unsuppressed lon strains were more sensitive to agents which appear to induce filamentation by inhibition of DNA synthesis than were those in which the Lon phenotype is suppressed. Thus Escherichia coli $\mathrm{B}$ and $E$. coli $\mathrm{B}_{8-12}$ were much more sensitive to inactivation by nalidixic acid and gentian violet than was $E$. coli $\mathrm{B} / \mathrm{r}$ (in which lon is suppressed by sul) or $E$. coli $\mathrm{B} / \mathrm{F}^{\prime} l o n^{+}$(in which $l o n^{+}$is dominant). However, the degree of sensitivity to these agents appears to be dependent on the mechanism by which lon is suppressed. Escherichia coli $\mathbf{B}_{8-2}$ and $E$. coli $\mathbf{B}_{\mathrm{s}_{-11}}$ in which lon is suppressed by $\operatorname{exr} A$ and $\operatorname{rec} A$ respectively were both more resistant to nalidixic acid and gentian violet than was $E$. coli B but they still were more sensitive to these compounds than was $E$. coli $\mathrm{B} / \mathrm{r}$.

The sensitivities of the strains to penicillin, however, reveal a rather different picture. Only suppression of lon by sul reduced sensitivity to penicillin. Suppression of lon by exrA or rec $A$ slightly increased rather than reduced sensitivity to penicillin. Therefore sensitivity to penicillin, which at low concentration induces filamentation by an effect on polymer murein biosynthesis (Schwarz, Asmus \& Frank, 1969; Hartmann, Holtje \& Schwarz, I972), 
was again highly dependent on the mechanism by which lon is suppressed. Moreover the introduction of $\mathrm{F}^{\prime}$ lon $^{+}$into Escherichia coli B did not reduce sensitivity. Although the $\mathrm{F}^{\prime}$ factor might have been responsible for this, this is unlikely, because the presence of $F^{\prime}$ in E. coli $\mathrm{B} / \mathrm{r} \mathrm{F}^{\prime}$ had little effect on its sensitivity to penicillin. Therefore the resistance of $E$. coli $\mathrm{B} / \mathrm{r}$ to penicillin is most likely the result of the expression of sul producing some effect in addition to direct suppression of lon. It is interesting that ten radiation-resistant mutants of the same u.v. sensitivity as $E$. coli $\mathrm{B} / \mathrm{r}$ which we have isolated from $E$. coli в by the method of Witkin (1947) were all much more resistant to penicillin than was the parent strain (unpublished results).

Because of the differences shown between agents which induce filamentation in lon strains by a specific action on DNA and on the bacterial envelope, it may be possible to deduce the site of action of other filament inducing compounds. For example, the observed sensitivities of Escherichia coli $\mathrm{B}, E$. coli $\mathrm{B}_{8 \cdot 2}$ and $E$. coli $\mathrm{B} / \mathrm{r}$ to crystal violet (Fig. 3) suggest that this agent induces filamentation in a manner analogous to nalidixic acid, i.e. by affecting DNA. This agrees with the conclusion of Witkin (196I) rather than that of Walker et al. (I97I), who suggested that it acted on the bacterial envelope.

The detailed processes involved in bacterial division are poorly understood but many authors (Clark, 1968; Helmstetter \& Pierucci, 1968; Donachie, 1969; Inouye, 1969) are agreed that there is probably a close relationship between completion of DNA synthesis and septum formation. Zusman, Inouye, \& Pardee (I972) have suggested that a specific protein produced at the end of a round of DNA replication may be involved in the coordination of these processes, possibly by binding to the membrane site at which septation is initiated. Although the mechanism by which lon interferes with the formation of a normal septum is unknown, Farnsworth \& James (1972) proposed that lon caused a defect in the bacterial envelope - a suggestion supported by the recent finding by Leighton (I972) that there is a deficiency in a protein component of the envelope of a lon strain of Escherichia coli $\mathrm{KI} 2$.

We propose that the lon-controlled envelope defect reduces the affinity of the septuminitiation site to bind the septum-promoting protein. This results effectively in an increase in the amount of the protein required to trigger septum formation, an increase which is normally met. However, because of the sensitivity of the binding site to reductions in the production of the protein, prevention of septum initiation readily occurs following inhibition of DNA synthesis.

Because of the marked effect of sul in reducing sensitivity to penicillin, which acts directly on the bacterial envelope, we propose that sul is also expressed as an alteration in the envelope. Sul may act, therefore, by countering the higher concentration of septumpromoting protein required in lon mutants, and thereby suppressing the Lon phenotype.

The mechanism of suppression of lon by the DNA repair mutations $\operatorname{rec} A$ and $\operatorname{exr} A$ is unknown. Farnsworth \& James (1972) found that these mutations affect the permeability properties of Escherichia coli $\mathrm{B}$, thus suggesting some interaction with the bacterial envelope. However, our results show that although these mutations reduce the lethal effect of filament inducing agents which act directly on the DNA (Fig. I, 2) they do not modify the penicillin sensitivity of $E$. coli в. This suggests that their site of action may also involve the coupling between DNA replication and septum formation, but is of a completely different nature from that involving sul.

The sensitivities of Escherichia coli $\mathrm{\text {в }}$ and $E$. coli $\mathrm{B}_{s-12}$ to each of the agents used were very similar, indicating that the $u v r$ gene had no effect on modifying survival under conditions of filament induction. This is as expected from our knowledge of the reactions controlled by 


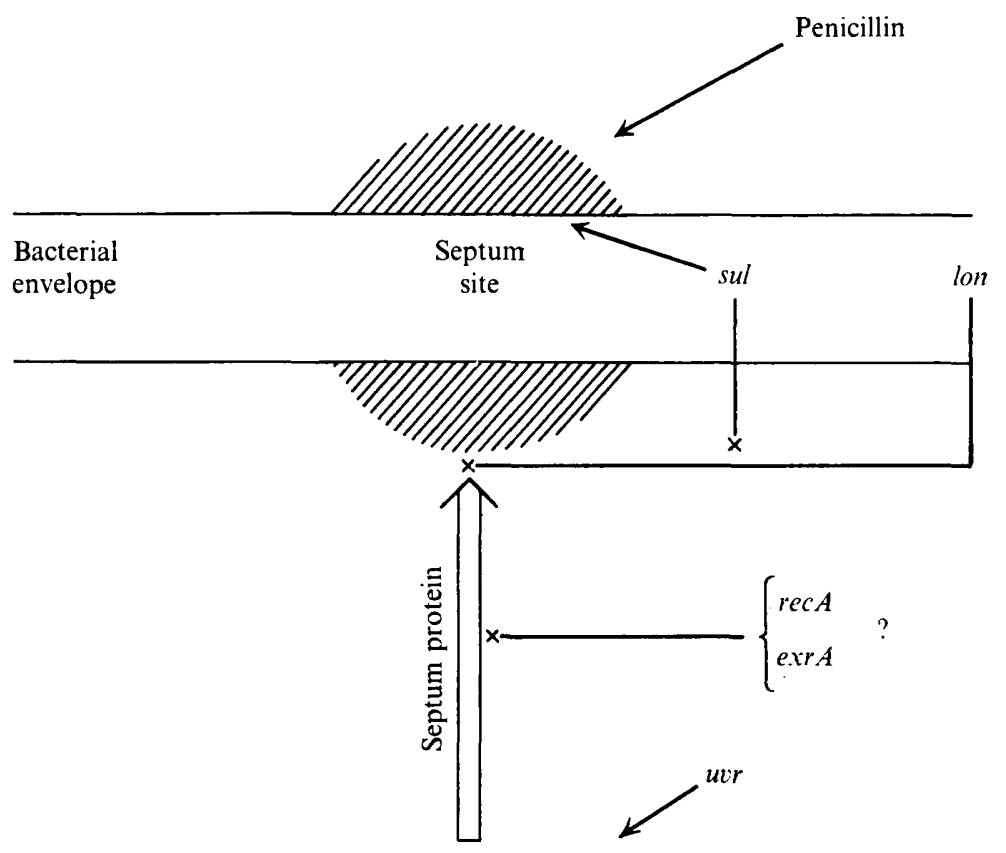

DNA replication
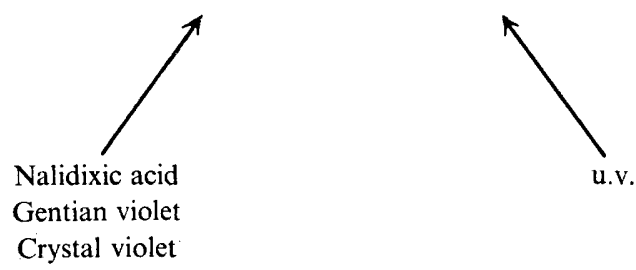

Fig. 5. A model of the control of bacterial division in lon strains of Escherichia coli. $\rightarrow$, Site of action of filament-inducing agents; $-\times$, site of suppression by mutant genes.

the $u v r$ genes and is consistent with the observation by Green et al. (1969) that $u v r$ does not suppress filament formation.

These conclusions are summarized in the model presented in Fig. 5, in which we indicate proposed sites of action of the filament inducing agents, the location of the lon lesion and the points at which suppression of lon by $s u l$, exr $A$ and $\operatorname{rec} A$ may occur. This model contains features of similarity to that proposed by Zusman et al. (I972). Whereas these authors postulated that in filamentous strains the lon mutation was expressed as a reduction in the amount of the septum-promoting protein produced following treatments which inhibit DNA synthesis, we suggest that the reduction in the amount of septum-initiation protein made is a consequence of the inhibition of DNA synthesis in both the Lon ${ }^{-}$and Lon ${ }^{+}$ strains. However, this leads to filamentation only in Lon- strains because of the reduced affinity of the septum site for the binding protein.

Nothing is known concerning the nature of the expression of the sul gene, but if, as we suggest, it interacts with lon by producing further alterations in the bacterial envelope, then it may be possible to detect these. This possibility is being tested by an examination of the 
envelope proteins of Escherichia coli $\mathrm{B}$ and one of the radiation-resistant mutants derived by us from $E$. coli B.

The mechanisms by which exr and rec suppress filamentation are also unknown, but our model predicts that these are not the same as those involving sul. Certainly, Holland \& Tuckett (1972) found that $r e c A$ did not alter the envelope protein profile of Escherichia coli. $\operatorname{Rec} A$ and $\operatorname{exr} A$ suppress production of bacteriophage in $E$. coli (Donch et al. 1968; Green, Greenberg \& Donch, 1969) whereas sul does not, but the reverse is true for suppression of mucoidy in E. coli KI2 1899 (Donch et al. I968; Donch et al. I97I), adding support to the view that $r e c$ and exr have no direct effect on the envelope but are involved in modifying effects on the bacterial genome.

We are grateful to Dr M. H. L. Green, M.R.C. Cell Mutation Unit, University of Sussex, and Dr E. Englesberg, Department of Biology, University of California, for providing us with bacterial strains and to Mr Neil Galvin for enthusiastic technical assistance. R.J. wishes to thank the Medical Research Council for a research studentship.

\section{REFERENCES}

Adler, H. I. \& Hardigree, A. A. (1965). Post-irradiation growth, division and recovery in bacteria. Radiation Research 25, 92-102.

AlPER, T. (1957). Observations on bacterial growth and morphology shortly after irradiation and some remarks on the oxygen effect. In Advances in Radiobiology, Proceedings of the Fifth International Conference on Radiobiology, pp. 90-96. Edited by G. C. de Hevesy, A. G. Forssberg and J. D. Abbatt. Edinburgh: Oliver and Boyd.

BoyCE, R. P. \& HowARD-Flanders, P. (1964). Release of ultraviolet light-induced thymine dimers from DNA in E. coli K-I 2. Proceedings of the National Academy of Sciences of the United States of America 51, 293-300.

Brown, D. \& Gillies, N. E. (1972). The relationship between filaments, killing and restoration in irradiated Escherichia coli strain B. Journal of General Microbiology 7o, 46I-470.

Clark, D. J. (1968). Regulation of deoxyribonucleic acid replication and cell division in Escherichia coli $\mathrm{B} / \mathrm{r}$. Journal of Bacteriology 96, $1214-1224$.

Donachie, W. D. (1969). Control of cell division in Escherichia coli: experiments with thymine starvation. Journal of Bacteriology roo, 260-268.

Donch, J., Chung, Y. S., Green, M. H. L., Greenberg, J. \& Warren, G. (I97I). Genetic analysis of sul mutants of Escherichia coli B. Genetical Research $17,185-193$.

Donch, J., Chung, Y. S. \& GreenberG, J. (I 969). Locus for radiation resistance in Escherichia coli strain B/r. Genetics 61, 363-370.

Donch, J., Green, M. H. L. \& Greenberg, J. (1968). Interaction of the exr and lon genes in Escherichia coli. Journal of Bacteriology 96, 1704-1710.

FARNSWORTH, P. A. \& JAMES, R. (1972). An effect of the LON phenotype in Escherichia coli as indicated by the growth of amoebae of Dictyostelium discoideum. Journal of General Microbiology 73, 447-454.

Green, M. H. L., Donch, J., Chung, Y. S. \& GreenberG, J. (1969). Effect of inhibition of DNA synthesis on u.v. sensitive Bs strains of Escherichia coli. Genetical Research 14, 1 I I-1 19.

Green, M. H. L., Greenberg, J. \& DonCh, J. (1969). Effect of a recA gene on cell division and capsular polysaccharide production in a lon strain of Escherichia coli. Genetical Research 14, I59-I62.

Hartmann, R., Holtje, J-V. \& Schwarz, U. (1972). Targets of penicillin action in Escherichia coli. Nature, London 235, 426-428.

Helmstetter, C. E. \& Pierucci, O. (I968). Cell division during inhibition of deoxyribonucleic acid synthesis in Escherichia coli. Journal of Bacteriology 95, 1627-1633.

Holland, I. B. \& TuCKeTt, S. (1972). Study of envelope proteins in E. coli cet and recA mutants by SDS acrylamide gel electrophoresis. Journal of Supramolecular Structure 1, 77-97.

Howard-Flanders, P. \& Boyce, R. B. (I966). DNA repair and genetic recombination: studies on Escherichia coli defective in these processes. Radiation Research Supplement 6, I56-184. 
INOUYE, M. (1969). Unlinking of cell division from deoxyribonucleic acid replication in a temperaturesensitive deoxyribonucleic acid synthesis mutant of Escherichia coli. Journal of Bacteriology 99, 842-850.

Kantor, G. J. \& Deering, R. A. (1968). Effect of nalidixic acid and hydroxyurea on division ability of Escherichia coli fil ${ }^{+}$and lon ${ }^{-}$strains. Journal of Bacteriology 95, 520-530.

Leighton, P. M. (1972). Gel electrophoresis of the cell envelope of a division mutant of Escherichia coli. Canadian Journal of Microbiology 18, I6I I-I6I4.

Leighton, P. M. \& Donachie, W. D. (1970). Deoxyribonucleic acid synthesis and cell division in a lonmutant of Escherichia coli. Journal of Bacteriology 102, 810-8I4.

MATTERN, I. E., ZWENK, H. \& RöRSCH, A. (1966). The genetic constitution of the radiation-sensititive mutant Escherichia coli $\mathbf{B}_{8-1}$. Mutation Research 3, 374-380.

Normark, S. \& Westling, B. (197I). Nature of the penetration barrier in Escherichia coli $\mathrm{K}-12$; effect of macromolecular inhibition on penetrability in strains containing the envA gene. Journal of Bacteriology I08, 45-50.

Rörsch, A., Edelman, A., Van Der Kamp, C. \& Cohen, J. A. (I962). Phenotypic and genotypic characterization of radiation sensitivity in Escherichia coli B. Biochimica et biophysica acta 6r, 278-289.

Rupp, W. D. \& HowARD-Flanders, P. (I968). Discontinuities in the DNA synthesized in an excisiondefective strain of Escherichia coli following ultraviolet irradiation. Journal of Molecular Biology 3r, $29 \mathrm{I}-304$.

Schwarz, U., Asmus, A. \& Frank, H. (1969). Autolytic enzymes and cell division. Journal of Molecular Biology 4I, 419-429.

SETlow, R. B. \& CARrier, W. L. (1964). The disappearance of thymine dimers from DNA: an errorcorrecting mechanism. Proceedings of the National Academy of Sciences of the United States of America 5I, 226-23I.

Van de Putte, P., Westenbroek, C. \& Rörsch, A. (1963). The relationship between gene-controlled radiation resistance and filament formation in Escherichia coli. Biochimica et biophysica acta 76, 247-256.

WAlker, J. R. \& PARdeE, A. B. (I968). Evidence for a relationship between deoxyribonucleic acid metabolism and septum formation in Escherichia coli. Journal of Bacteriology 95, I23-I 3 I.

Walker, J. R., Shafiq, N. A. \& Allen, R. G. (197I). Bacterial cell division regulation: physiological effects of crystal violet on Escherichia coli lon ${ }^{+}$and lon- strains. Journal of Bacteriology 108, 1296-1 303.

WITKIN, E. M. (1947). Genetics of resistance to radiation in Escherichia coli. Genetics 32, 221-248.

WITKIN, E. M. (I96I). Modification of mutagenesis initiated by ultraviolet light through post-treatment of bacteria with basic dyes. Journal of Cellular and Comparative Physiology 58 (Suppl I), I35-I44.

Zusman, D. R., Inouye, M. \& PARdee, A. B. (1972). Cell division in Escherichia coli: evidence for regulation of septation by effector molecules. Journal of Molecular Biology 69, I 19-136. 